\title{
Effect of a highly concentrated lipopeptide extract of Bacillus subtilis on fungal and bacterial cells
}

\author{
Augusto Etchegaray • Carolina de Castro Bueno • Itamar Soares de Melo • \\ Siu Mui Tsai • Marli de Fátima Fiore • Maria Estela Silva-Stenico • \\ Luiz Alberto Beraldo de Moraes · Omar Teschke
}

Received: 29 January 2008 / Revised: 30 June 2008 / Accepted: 3 July 2008 / Published online: 25 July 2008

(C) Springer-Verlag 2008

\begin{abstract}
Lipopeptides produced by Bacillus subtilis are known for their high antifungal activity. The aim of this paper is to show that at high concentration they can damage the surface ultra-structure of bacterial cells. A lipopeptide extract containing iturin and surfactin $\left(5 \mathrm{mg} \mathrm{mL}^{-1}\right)$ was prepared after isolation from $B$. subtilis (strain OG) by solid phase extraction. Analysis by atomic force microscope (AFM) showed that upon evaporation, lipopeptides form large aggregates $\left(0.1-0.2 \mu \mathrm{m}^{2}\right)$ on the substrates silicon and mica. When the same solution is incubated with fungi and bacteria and the system is allowed to evaporate, dramatic changes are observed on the cells. AFM micrographs show disintegration of the hyphae of Phomopsis phaseoli and the cell walls of Xanthomonas campestris and X. axonopodis. Collapses to fungal and bacterial cells may be a result of
\end{abstract}

Communicated by Jorge Membrillo-Hernández.

A. Etchegaray $(\bowtie) \cdot C$. de Castro Bueno

Faculdade de Química, PUC-Campinas,

C. Postal 317, Campinas, SP 13012-970, Brazil

e-mail: augusto.etchegaray@ puc-campinas.edu.br

I. S. de Melo

Laboratório de Microbiologia,

Embrapa Meio Ambiente, Jaguariuna, SP, Brazil

S. M. Tsai · M. de Fátima Fiore · M. E. Silva-Stenico

CENA, Universidade de São Paulo,

C. Postal 96, Piracicaba, SP 13400-970, Brazil

L. A. B. de Moraes

Departamento de Química, Universidade de São Paulo,

Av. Bandeirantes, Ribeirão Preto, SP 14100-000, Brazil

O. Teschke

Laboratório de Nanoestruturas e Interfaces,

Instituto de Física, UNICAMP,

Campinas, SP 13083-970, Brazil formation of pores triggered by micelles and lamellar structures, which are formed above the critical micelar concentration of lipopeptides. As observed for $P$. phaseoli, the process involves binding, solubilization, and formation of novel structures in which cell wall components are solubilized within lipopeptide vesicles. This is the first report presenting evidences that vesicles of uncharged and negatively charged lipopeptides can alter the morphology of gramnegative bacteria.

Keywords Antimicrobial peptides $\cdot$ Non-ribosomal peptides · Lipopeptides · Iturin · Surfactin · Atomic force microscope $\cdot$ Bacillus subtilis $\cdot$ Xanthomonas

\author{
Abbreviations \\ AFM Atomic force microscope \\ NRPS Non-ribosomal peptide synthetase \\ OM Optical microscopy \\ PKS Polyketide synthase \\ PE Plant emergence \\ PH Plant height \\ PDW Plant dry weight \\ Xac Xanthomonas axonopodis pv. citri \\ Xcc Xanthomonas campestris pv. campestris
}

\section{Introduction}

Several lipopeptides produced non-ribosomally have been identified in extracts of Bacillus subtilis. These can be grouped in three different classes; the surfactin, fengycin, and iturin families. Members of the surfactin and fengycin groups are composed of one $\beta$-hydroxy fatty acid and seven (surfactins) or ten (fengycins) $\alpha$-amino acids, while members of the iturin family contain a $\beta$-amino fatty acid linked 
to seven $\alpha$-amino acids. The presence of the $\beta$-amino fatty acid is the most striking characteristic of the iturin A family and distinguishes this group from the other two (MagetDana and Peypoux 1994; Leclère et al. 2005). In all lipopeptide classes, the length of the fatty acid chain is variable, a minimal of 13 carbons is observed in surfactins, whereas in iturins the length starts with $\mathrm{C}_{14}$ to a maximum of $\mathrm{C}_{17}$, and $\mathrm{C}_{18}$ for fengycins. Thus homologous lipopeptides within each family can be found in Bacillus extracts (Razafindralambo et al. 1997).

Due to their size and amphipatic character, iturin A has a tendency to associate and form small vesicles (Grau et al. 2001), inducing the formation of pores in biological membranes (Aranda et al. 2005). In the specific interaction of iturins with phosphatidylcholine it was shown that these lipopeptides are arranged in small mixed-vesicles complexed with phosphatidylcholine molecules (Grau et al. 2001). Iturins also form aggregates with surfactins when both are present (Razafindralambo et al. 1997). The latter characteristic may also explain the synergistic effect of surfactin on the antifungal activity of iturins (Maget-Dana et al. 1992).

Iturins are interesting membrane-active antimicrobials, generally effective against fungal pathogens (Maget-Dana and Peypoux 1994; Romero et al. 2007). However, it has also been reported that iturins are effective against the phytopathogenic bacterium Xanthomonas campestris pv. campestris (Xcc) (Monteiro et al. 2005).

Microscopic examination of ultra-thin sections of yeast cells revealed that iturin A exerts its effect on the cytoplasmic membrane. Upon interaction with this lipopeptide, electrolytes, and other cytoplasmic components of yeast cells are released owing to an alteration of cell permeability and formation of pores (Thimon et al. 1995). However, no experiments have shown the results of a direct interaction of these non-ribosomal peptides with bacterial or fungal cells under the atomic force microscope (AFM). AFM provides three-dimensional images of the surface ultra-structure at molecular resolution. The technique requires minimal sample preparation and yet provides insights on the structure of microbial membranes (Dufrêne 2002). Most of the studies with AFM describe the interaction of positively charged peptides (mostly of ribosomal origin), which attach to the negatively charged cell wall of gram-negative bacteria and induce morphological modifications of the cells (da Silva and Teschke 2003; Meincken et al. 2005). The membrane of gram-negative bacteria, which is the target of most antimicrobial peptides, is not easily transposed by neutral and negatively charged peptides. A positive charge in the structure of the antibiotic is important for binding. The interaction of positively charged peptides with the negative surface of these cell walls is described by the carpet-binding and toroidal models (Meincken et al. 2005;
Allende et al. 2005). To our knowledge, the internalization of neutral peptides by gram-negative bacteria following similar models has not been described yet, except for siderophores, which bind to specific receptors (Sprencel et al. 2000).

In the present study, considering the soil environment where pathogenic microbes coexist with beneficial rhizobacteria, we selected to study the effect of lipopeptides produced by a plant-growth promoting rhizobacteria on fungal and bacterial pathogens. For this goal AFM topographic images were obtained, demonstrating dramatic morphological modifications induced by lipopeptide aggregates on Xcc cells. Production of antibiotics is also important for the growth promoting Pseudomonas spp. that induces suppression of the root disease of wheat (Cook et al. 1995). The results presented by AFM demonstrate the competence of iturin and surfactin-producing strains of Bacillus spp. to control fungal and bacterial pathogens.

\section{Materials and methods}

Strains and media

Strains of Bacillus spp. used in this work corresponding to field isolates collected from soybean and bean fungal pathogens were identified by morphological and biochemical methods (Ivanova et al. 1999). Bacillus subtilis (strain OG), was further characterized by genetic methods (described below). Fungal pathogens were obtained from the culture collection of the laboratory of microbiology, EMBRAPA Jaguariúna, SP, Brazil. Xcc and Xanthomonas axonopodis pv. citri (Xac), were a gift of Dr. Jesus A. Ferro (Universidade Estadual Paulista, UNESP, Jaboticabal, São Paulo, Brazil). Bacillus spp. was grown in Nutrient growth media (liquid and solid) at $28^{\circ} \mathrm{C}$, whereas fungal strains were incubated in Potato Dextrose Agar (PDA). The Xanthomonas strains were inoculated from glycerol stocks on YCD agar plates (Kim et al. 2003) and were grown for 3 days at $28^{\circ} \mathrm{C}$.

\section{Effect of rhizobacteria on plant growth}

Soybean seeds from Embrapa seed collection were used. Measurements of plant emergence, plant height $(\mathrm{PH})$, weights of aerial and root parts of the soybean plants were obtained. Experiments were organised in a completely randomised block design using one factor, 27 levels, four repetitions and six seeds for each repetition. Plant emergence (PE) experiments were designed in balanced randomised blocks, whereas the parameters of $\mathrm{PH}$, aerial part- and root dry weight were designed using unbalanced completely randomised blocks. Seeds were superficially sterilised by treatment 
with alcohol (70\% ethanol, 3 min) and commercial sodium hypochlorite $(5 \mathrm{~min})$ followed by several washing steps in sterile water. After draining, they were imbedded in a suspension of rhizobacteria (approximately $10^{7} \mathrm{CFU} \mathrm{mL}^{-1}$ ) and aseptically transferred to vases filled with non-sterile soil. Plant parameters were measured after 29 days of cultivation in the green house at temperatures ranging between 25 and $28^{\circ} \mathrm{C}$. Measurements of $\mathrm{PH}$ were performed on the first day after harvest. Further determinations were obtained after rinsing the plants with water and drying at $105^{\circ} \mathrm{C}$.

\section{Antimicrobial activity}

\section{In vitro assay}

Dual culture assays were performed by co-cultivation experiments in PDA plates (Petri dishes). Plates were preliminarily inoculated with a disc $(0.8 \mathrm{~cm}$ diameter $)$ of Phomopsis phaseoli pv. meridionalis, which was removed from a 5-day-old culture grown at $28^{\circ} \mathrm{C}$ in PDA. The plug containing fungal mycelia was placed at $1.5 \mathrm{~cm}$ from one of the edges of the plate and incubated $24 \mathrm{~h}$ before the addition of the antagonist bacteria. Twenty micro liter of a cell suspension (approximately $10^{10}$ cell $\mathrm{mL}^{-1}$ ) of the corresponding Bacillus strain was streaked at $1.5 \mathrm{~cm}$ of the opposite edge of the plate keeping a distance $(4 \mathrm{~cm})$ from the fungal inoculum. Paired cultures were incubated at $28^{\circ} \mathrm{C}$ for 3 days and inhibition was determined by measuring the distance between $P$. phaseoli and the corresponding Bacillus strain in comparison with a control without antagonist that was incubated along with the other Petri dishes.

\section{Bioassay of lipopeptides}

The inhibitory activity of iturins produced by selected Bacilli was evaluated by an agar diffusion method on PDA plates. Plates were inoculated with agar discs of the fungal strains on one side of the plate and with paper discs for addition of metabolites on the opposite side. Discs were placed at $1 \mathrm{~cm}$ from each of the edges of the plate and were diagonally separated by a distance of $8 \mathrm{~cm}$. After solid-phase extraction (described below), lipopeptides were diluted to a concentration of $10 \mathrm{mg} \mathrm{mL}^{-1}$ in $100 \%$ methanol. Five micro liter of lipopeptide solution was added directly on the filter discs. All operations were performed under sterile conditions. The inhibitory activity was estimated from measurements of fungal growth across the line separating the discs compared to a control in which only methanol was added.

\section{Extraction of lipopeptides}

Production of anti-fungal lipopeptides by novel isolates of B. subtilis was evaluated using previously described growth conditions (Besson et al. 1976) and extraction procedure (Razafindralambo et al. 1993). Cells were grown in liquid media and metabolites were extracted from the supernatant on $\mathrm{C}-18$ cartridges (Extract-clean Hi-Load $10 \mathrm{~g} \mathrm{C}-18$ cartridge, Altech Associates Inc., Deerfield, IL).

Culture supernatants were loaded onto cartridges and the hydrophobic material was eluted as described below. Columns were firstly washed with $50 \%$ methanol in water, followed by elution of lipopeptides with $100 \%$ methanol. After elution, extracts were concentrated under vacuum and analysed by high performance liquid chromatography (HPLC) using the Äkta Basic system (Amersham Pharmacia Biotech UK Limited, Buckinghamshire, England) equipped with a continuous absorption monitor in the range of 190-900 nm. Peaks were monitored in the wavelengths of 214, 254 and $280 \mathrm{~nm}$. Chromatography followed conditions previously described (Razafindralambo et al. 1993). The HPLC column was pepRPC HR 5.5 (a C2-C18 reversed-phase column). An elution gradient was prepared with solvent A ( $0.1 \%$ TFA in water) and solvent B [0.1\% TFA in water:acetonitrile (30:70)]. Gradient conditions were set: $0-45 \%$ B $(20 \mathrm{~mL})$; $45 \%-60 \%$ B $(11 \mathrm{~mL}) ; 60 \%$ $80 \%$ B $(11 \mathrm{~mL}) ; 80-100 \%$ B $(0 \mathrm{~mL}) ; 100 \%$ B $(5 \mathrm{~mL})$. Under the above conditions, iturin A (generously given by Doctor Alan Lax, USDA, USA) was eluted at $25 \mathrm{~min}$.

Determination of minimum inhibitory concentrations (MIC)

Cells of Xac and Xcc were incubated with diluted lipopeptide solutions as described. Bacterial cells were grown in liquid media to an absorbance (OD600 nm) of 0.6-0.8. Cells were collected by centrifugation and resuspended in Tris-HCl $20 \mathrm{mmol} \mathrm{L}^{-1}$, $\mathrm{pH}$ 8.0. These were adjusted to an OD600 $\mathrm{nm}$ of 0.4 in the presence of the following concentrations of lipopeptides dissolved in the same buffer and sterilized by filtration: $\left(135 \mathrm{mg} \mathrm{mL}^{-1} ; 67.5 \mathrm{mg} \mathrm{mL}^{-1}\right.$; $33.75 \mathrm{mg} \mathrm{mL}^{-1}$ and $13.5 \mathrm{mg} \mathrm{mL}^{-1}$ ). After $60 \mathrm{~min}$ of incubation, cells were diluted and transferred to Petri dishes containing YCD media and incubated. Duplicate plates were prepared for each dilution. Analysis of colony forming units (cfu) was performed after 3 days of incubation at $28^{\circ} \mathrm{C}$. The MIC was considered based on a reduction of cfu greater than $50 \%$.

\section{Mass spectrometry (MS) analysis}

MS analyses were performed in a hybrid quadrupole timeof-flight (Q-TOF) mass spectrometer from Micromass (Manchester, UK) equipped with an electrospray ion source (ESI). Experiments were performed under high resolution and high accuracy $(5 \mathrm{ppm})$. Conditions for positive ESI were as follows, the desolvatation gas $\left(\mathrm{N}_{2}\right)$ was heated at 
$150^{\circ} \mathrm{C}$, the capillary was held at a potential of $3.5 \mathrm{kV}$, and the cone voltage was $25 \mathrm{~V}$. The lipopeptide extract of $B$. subtilis was dissolved in a mixture of methanol and formic acid 1:1 (v/v) and analyzed in positive ion mode. Sample was introduced into the source at $5 \mu \mathrm{L} \mathrm{min}{ }^{-1}$ with a syringe pump.

Strain characterization by molecular biology

Cells from strain $0 \mathrm{G}$ were collected by centrifugation at $13,000 \mathrm{~g}$ for $15 \mathrm{~min}$ at $4^{\circ} \mathrm{C}$. The pellet was washed three times with sterilized ultrapure water (centrifuged at $13,000 \times g$ for $15 \mathrm{~min}$ at $4^{\circ} \mathrm{C}$ ) and stored at $-20^{\circ} \mathrm{C}$. After thawing the stored samples, the DNA was extracted using the FastDNA Kit (QBiogene, Carlsbad, CA, USA) according to the manufacture's specifications. Integrity of the extracted DNA was verified by electrophoretic analysis using $1 \%$ agarose gel stained with ethidium bromide. Gels were viewed on a Fluor-S MultiImager (BioRad, Hercules, CA, USA) and recorded.

The 16S rRNA sequence was amplified from genomic DNA using the specific primer-set 27F1 and 1494R (Neilan et al. 1997). Amplification was performed in a $25 \mu \mathrm{L}$ polymerase chain reaction (PCR) containing $10 \mathrm{ng}$ of genomic DNA, 5 pmol $\mu \mathrm{L}^{-1}$ of each oligonucleotide primer, $10 \mathrm{mM}$ of each dNTP, $50 \mathrm{mM} \mathrm{MgCl} 2,10 \times$ PCR buffer and $5 \mathrm{U}$ Platinum Taq DNA polymerase (Invitrogen, Carlsbad, CA, USA). A Gene Amp PCR System 2400 (Applied Biosystems, Foster City, CA, EUA) was used. Thermal cycling was performed with an initial denaturation step at $94^{\circ} \mathrm{C}$ for 4 min, followed by 30 cycles of DNA denaturation at $94^{\circ} \mathrm{C}$ for $20 \mathrm{~s}$, primer annealing at $50^{\circ} \mathrm{C}$ for $30 \mathrm{~s}$, strand extension at $72^{\circ} \mathrm{C}$ for $2 \mathrm{~min}$, and a final extension step at $72^{\circ} \mathrm{C}$ for $7 \mathrm{~min}$. PCR products were analyzed by electrophoresis. New PCR products were cloned using a pGem-T Easy kit (Promega, Madison, WI, USA) according to manufacturer's instructions. Competent E. coli DH5 $\alpha$ cells were used for transformations. Recombinant plasmids were isolated from specific clones according to standard procedures (Birnboim and Doly 1979). For DNA sequencing the DYEnamic ET Terminator Cycle Sequencing Kit from Amersham Biosciences (UK) was used. An external and three internal primer sets (Lane 1991) were used for the complete sequencing of the $16 \mathrm{~S}$ rRNA. The cycle sequencing reaction included 25 cycles of $10 \mathrm{~s}$ at $95^{\circ} \mathrm{C}, 5 \mathrm{~s}$ at $50^{\circ} \mathrm{C}$, and $4 \mathrm{~min}$ at $60^{\circ} \mathrm{C}$. After the sequencing reaction was completed, samples were sequenced in an ABI PRISM 310 Genetic Analyzer (Applied Biosystems) following manufacturer's instructions.

The 16S rRNA sequences obtained in this study were aligned with related sequences retrieved from GenBank using the Clustal X program (Thompson et al. 1997). Phylogenetic trees were constructed by neighbour-joining (NJ) and maximum-parsimony (MP) algorithms using the
MEGA package version 3.1 (Kumar et al. 2004). The NJ and MP stability of the relationships was assessed by bootstrapping (1,000 replicates). Comparative sequence analysis by BLAST (Altschul et al. 1990) involved selection of the closest cultured strain when the best hit came from uncultured clones.

The 16s rRNA sequence was deposited in GenBank under accession number EF666489.

\section{Atomic Force Microscope}

Fungal and bacterial cells were either directly added to mica or previously incubated with lipopeptides. A loop full of bacterial cells or fungal mycelia was suspended in $1 \mathrm{~mL}$ of water before the addition of lipopeptides. Lipopeptides were incubated with cells at room temperature for $15 \mathrm{~min}$, after which a drop of $10 \mu \mathrm{L}$ of the suspension was deposited on mica. Before analysis the latter sample was left to evaporate for $24 \mathrm{~h}$ under $\sim 60 \%$ humidity.

The ThermoMicroscope AutoProbe CP was used for these experiments. A cantilever with ultra-low spring constants $\left(\sim 0.03 \mathrm{~N} \mathrm{~m}^{-1}\right.$, Park Scientific Instruments, Mountain View, CA, USA) allowed probing bacterial cells by contact mode without any physical damage. Before measurements, the size and shape of AFM probes were characterized using a reference sample of titanium. The imaging force was kept below $1 \mathrm{nN}$ and the scan rate in the range of 1-4 Hz. The software TopoMetrix SPMLab, 4.0 was used to analyze AFM data. For additional morphological analyses the software SPM Image Magic (http://www.geocities. com/SiliconValley/Network/6216/) was used. Lipopeptides directly added to substrates (silicon and mica) were dehydrated as above and analyzed in the non-contact mode. Silicon wafers with a resistivity of $10 \Omega \mathrm{cm}^{-1}$ (Virginia Semiconductor, Inc., VA, USA) were used. Fragments of approximately $1 \times 1 \mathrm{~cm}^{2}$ were fixed in a $50 \%$ solution of HF for a few minutes and then rinsed with water. Muscovite mica from Mica New York Co (NY, USA) was used. Samples were deposited on freshly cleaved mica.

\section{Results}

Selection of competent strains of Bacillus spp

Strains were chosen based on their contribution for plant growth. The effects of rhizobacteria on the emergence of soybean were evaluated by growing the plants for 30 days in non-sterile soil. After treatment with 16 different isolates of Bacillus spp., the parameters of PE, PH and plant dry weight (PDW) were measured. PDW (including aerial and root parts) was used to compare the effects of Bacillus spp. with a control that received no treatment (Table 1). The 
Table 1 Parameters of soybean plants treated with Bacillus spp.

\begin{tabular}{lclll}
\hline Isolate & $\begin{array}{l}\text { Plant } \\
\text { height }^{\mathrm{a}, \mathrm{b}}(\mathrm{cm})\end{array}$ & $\begin{array}{l}\text { Height } \\
\text { gain }^{\mathrm{c}}(\%)\end{array}$ & $\begin{array}{l}\text { Plant dry } \\
\text { weight }^{\mathrm{a}, \mathrm{b}}(\mathrm{mg})\end{array}$ & $\begin{array}{l}\text { Weight } \\
\text { gain }^{\mathrm{c}}(\%)\end{array}$ \\
\hline Control & $8.4 \pm 0.9(17)$ & - & $178 \pm 33(17)$ & - \\
G2-6 & $9.9 \pm 1.0(13)$ & $18 \pm 1.9$ & $193 \pm 35(13)$ & $8 \pm 0.9$ \\
G7-6 & $8.3 \pm 0.8(10)$ & - & $196 \pm 38(10)$ & $10 \pm 1.2$ \\
G3-6C & $9.0 \pm 1.1(11)$ & $7 \pm 0.8$ & $184 \pm 32(11)$ & $3 \pm 0.3$ \\
G2-7 & $8.4 \pm 1.1(10)$ & - & $174 \pm 27(10)$ & - \\
5G & $9.0 \pm 1.3(15)$ & $7 \pm 0.9$ & $180 \pm 30(15)$ & $1 \pm 0.1$ \\
G1-6 & $9.8 \pm 1.6(15)$ & $17 \pm 1.9$ & $198 \pm 40(15)$ & $11 \pm 1.0$ \\
G4-6 & $8.8 \pm 1.5(15)$ & $5 \pm 0.5$ & $178 \pm 26(15)$ & - \\
0G & $10.6 \pm 1.9(9)$ & $26 \pm 2.8$ & $198 \pm 37(10)$ & $11 \pm 1.2$ \\
G11-6 & $9.0 \pm 1.6(17)$ & $7 \pm 0.6$ & $163 \pm 25(18)$ & - \\
G3-6B & $9.1 \pm 1.4(11)$ & $8 \pm 0.9$ & $187 \pm 28(11)$ & $5 \pm 0.6$ \\
G11-5A & $10.7 \pm 2.0(14)$ & $27 \pm 3.0$ & $208 \pm 39(14)$ & $17 \pm 1.9$ \\
G8-7 & $10.8 \pm 1.7(14)$ & $29 \pm 3.0$ & $187 \pm 30(15)$ & $5 \pm 0.6$ \\
G6-7 & $8.9 \pm 1.0(13)$ & $6 \pm 0.7$ & $193 \pm 30(13)$ & $8 \pm 0.9$ \\
G9-6 & $9.1 \pm 1.3(11)$ & $8 \pm 0.9$ & $197 \pm 35(11)$ & $11 \pm 1.3$ \\
18-G & $9.5 \pm 1.4(12)$ & $13 \pm 1.4$ & $142 \pm 21(12)$ & - \\
G10-5C & $10.2 \pm 1.6(14)$ & $21 \pm 2.3$ & $144 \pm 22(15)$ & - \\
\hline
\end{tabular}

Plants were inoculated in non-sterile soil after treatment with isolates of Bacillus. The results presented correspond to an average of six repetitions with the number of plants for each repetition indicated in parenthesis

${ }^{\text {a }}$ Unbalanced-totally random

b Values in parenthesis represent the number of evaluated plants

${ }^{c}$ Height and weight gains were calculated by subtracting the average measured parameters from those obtained for plants that received no treatment (control)

results demonstrate that most of the strains contribute for plant growth. Selected strains were chosen for antifungal activity tests based on higher values of weight gain, calculated from the corresponding PDW.

\section{Characterization of best isolates}

Antifungal activity in dual-culture assays demonstrated that ten isolates of B. subtilis were inhibitory to $P$. phaseoli, presenting average growth inhibitory activity in the order of $40 \%$. B. subtilis (strain OG), was considered the best antagonist of this fungus, with an average inhibitory activity of $63 \%$. Experiments were repeated at least three times and presented a standard deviation (sd) of the mean of approximately $10 \%$.

After solid-phase extraction, the lipopeptide fraction of selected strains (OG, 18G and G2-6) was adjusted to $5 \mathrm{mg} \mathrm{mL}^{-1}$ in methanol, demonstrating inhibitory activity against Rhizoctonia solani and Sclerotinia sclerotiorum in agar plates. Average inhibition on the growth of the latter fungi was in the order of $14 \%$ (sd $\sim 10 \%$ ). The analyzed strains (OG, 18G and G2-6) presented lipopeptides of the iturin and surfactin types as determined by HPLC (Fig. 1). Approximately $100 \mu \mathrm{g}$ of extracted lipopeptides was injected in each analysis. The presence of iturin $\mathrm{A}$ in the extracts was confirmed by comparison with a standard. Additional lipopeptides were identified, potentially surfactins that according to Razafindralambo et al. (1993) are eluted at the end of the gradient. Considering that the latter late-peaks may correspond to surfactin, the HPLC peaks were accordingly labelled iturin- and surfactin-like peptides (Fig. 1). Mass-spectrometry analysis confirmed the presence of two isoforms of iturin (iturin A and iturin D), corroborated by tandem mass-spectrometry of the respective molecular ions $[\mathrm{M}+\mathrm{H}]^{+}$at $\mathrm{m} / z, 1043$ and $\mathrm{m} / z, 1057$ (both indicated in Fig. 1b), which gave a fragmentation pattern similar to previously obtained by Gong et al. (2006).

Strain characterization by molecular biology

According to the 16s rRNA sequence analysis (Fig. 2), strain OG was most closely related to other B. subtilis strains, presenting $99 \%$ of sequence identity with all of the sequences used in the current analysis, being thus classified B. subtilis. Additional evidences that characterize the strain are amplification of non-ribosomal peptide synthetase (NRPS)-polyketide synthase/fatty acid synthase (PKS/ FAS) genes using a multiplex PCR reaction (Etchegaray et al. 2004a). Performing such DNA amplification we obtained a PCR fragment of $\sim 2.5$ kbase (data not shown), which is the expected size for the hybrid NRPS-FAS module of the NRPS involved in the biosynthesis of iturins (Tsuge et al. 2001).

\section{Auto-organization of lipopeptides}

A drop $(10 \mu \mathrm{L})$ of a highly concentrated lipopeptide solution $\left(5 \mathrm{mg} \mathrm{mL}^{-1}\right)$ was added to silicon and muscovite mica and the system was allowed to dry for at least $24 \mathrm{~h}$ before analysis by AFM. Micrographs are shown in Fig. 3, where one can see the formation of aggregates in both substrates. On mica, the diameters of putative micelles are in the range of $150-300 \mathrm{~nm}$, which correspond to aggregates with an area within $\left(0.1-0.2 \mu \mathrm{m}^{2}\right)$. Larger aggregates may correspond to vesicles or lamellar structures, while those with diameters of about $150 \mathrm{~nm}$ may constitute micelles. However, possibly due to dehydration, layers of lipopeptides are formed making the structure grow vertically with peaks in the range of 4-5 nm (Fig. 3b). When the sample is allowed to dry on the substratum different patterns are observed on mica and silicon. The polar surface of mica contributes for spreading (Fig. 3a-b), whereas the hydrophobic surface of silicon concentrates solute at the border of the drop contributing to formation of larger aggregates (Fig. 3d), when compared to the center of the drop (Fig. 3c). 

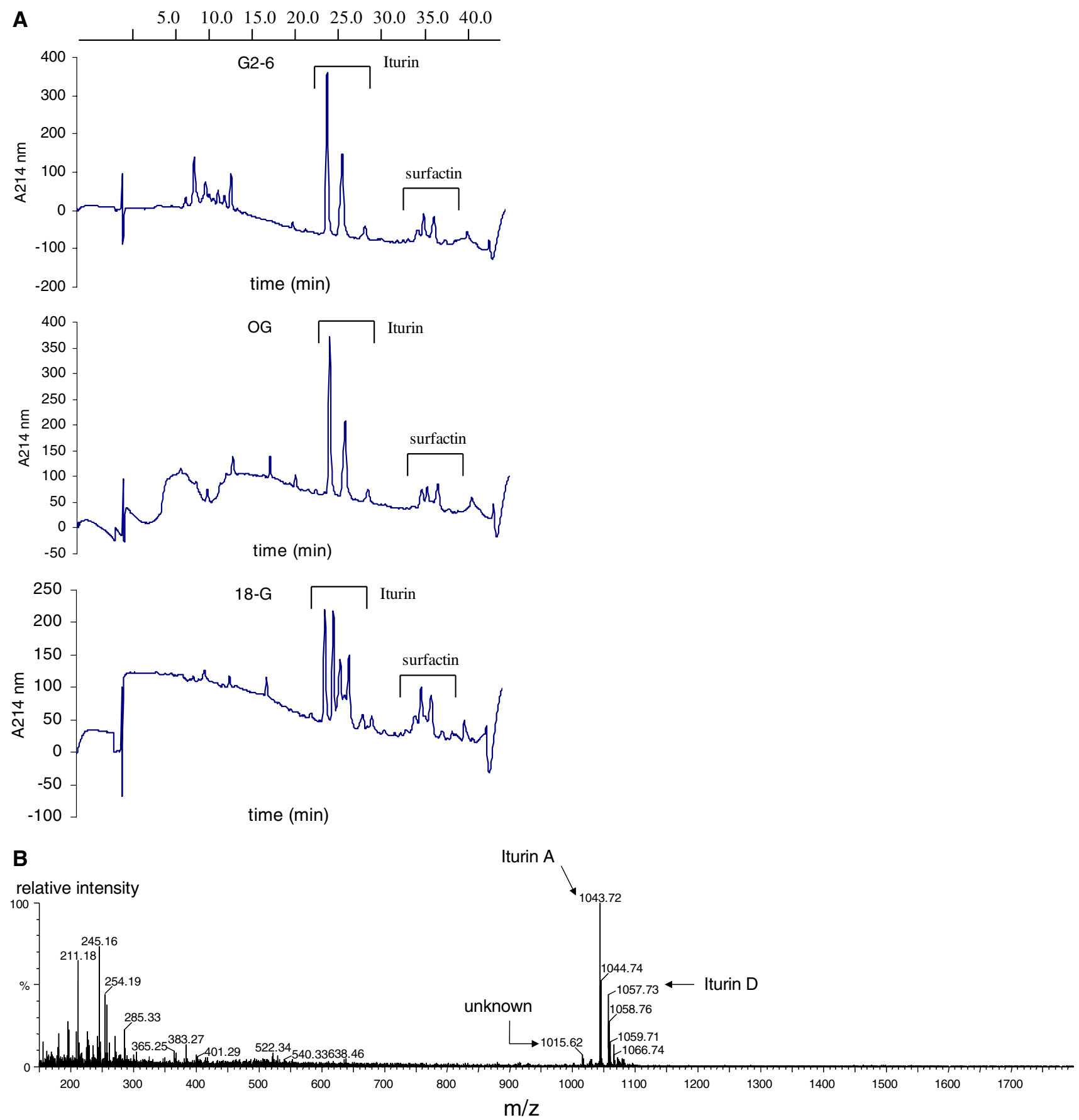

Fig. 1 Analysis of the lipopeptide extract of B. subtilis (strains G2-6, $0 \mathrm{G}$ and $18 \mathrm{G}$ ) after solid-phase extraction. a HPLC chromatograms. b Q-TOF spectrum of the lipopeptide extract of strain $0 \mathrm{G}$, confirming the presence of iturin A, molecular ion $[\mathrm{M}+\mathrm{H}]^{+} \mathrm{m} / z, 1043 \mathrm{Da}$; iturin

\section{Effect of lipopeptides on fungal mycelium}

The soybean pathogen Sclerotium rolfsii was analyzed by optical microscopy (OM) and AFM before and after treatment with the isolated lipopeptides of strain OG. Iturin solutions with a concentration above the reported critical micelar concentration (CMC) of 20-80 $\mu \mathrm{M}$ (Maget-Dana and Pey-
$\mathrm{D}$, molecular ion $[\mathrm{M}+\mathrm{H}]^{+} \mathrm{m} / z, 1057 \mathrm{Da}$. The peak labelled "unknown" may correspond to a surfactin isoform, molecular ion $[\mathrm{M}+\mathrm{Na}]^{+}(\mathrm{m} / z)$ $1,015 \mathrm{Da}$

poux 1994) were used. Figure 4 shows the effect of lipopeptides on fungal hyphae. A reduction in hyphae structure is observed due to solubilization of cell wall by putative lipopeptide vesicles. Concomitantly, a novel structure is formed possibly composed by aggregates of lipopeptide and solubilized cell wall in addition to intracellular material. These mixed aggregates are formed with a $5 \mathrm{mM}$ solution of 
Fig. 2 Phylogenetic characterization of isolate OG. The tree is based on the alingnment of $16 \mathrm{~S}$ rRNA sequences. Numbers near the nodes indicate bootstrap values over $50 \%$ for $\mathrm{NJ}$ and MP analyses. The sequence corresponding to Bacillus subtilis strain OG is highlighted

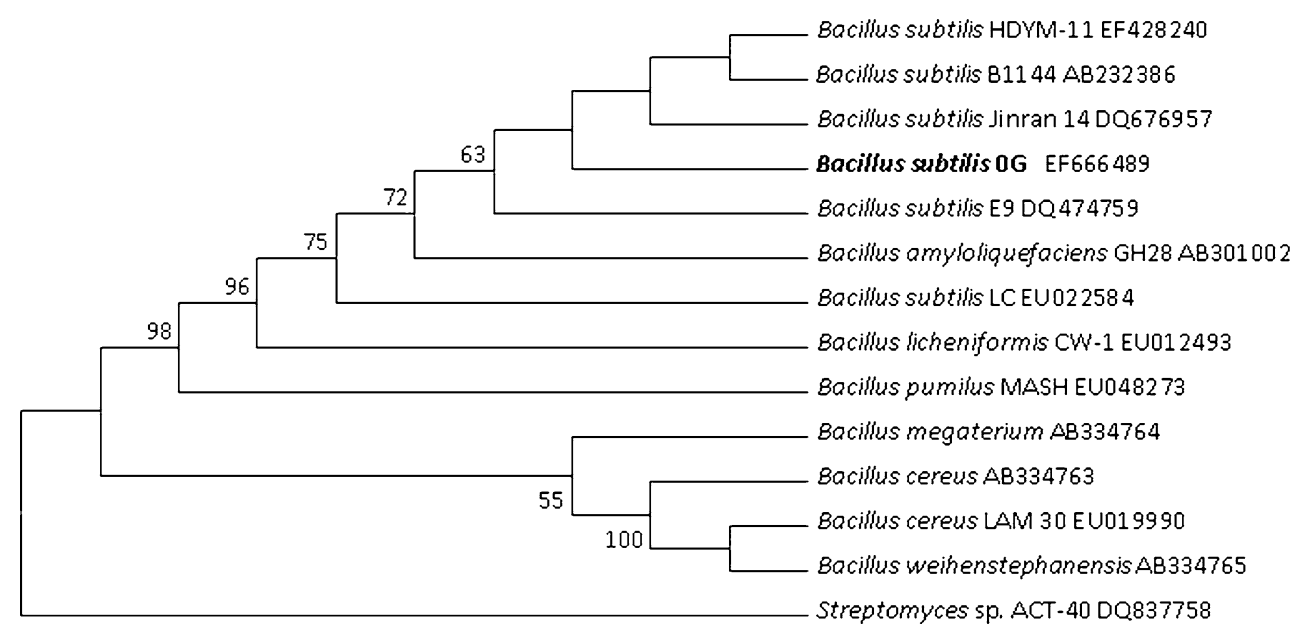

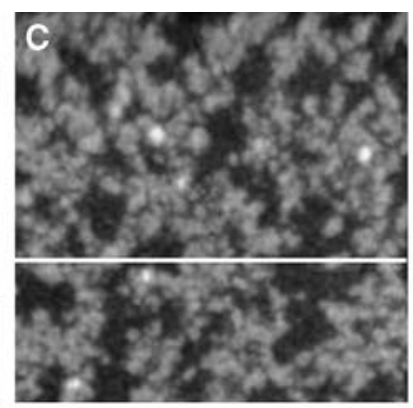
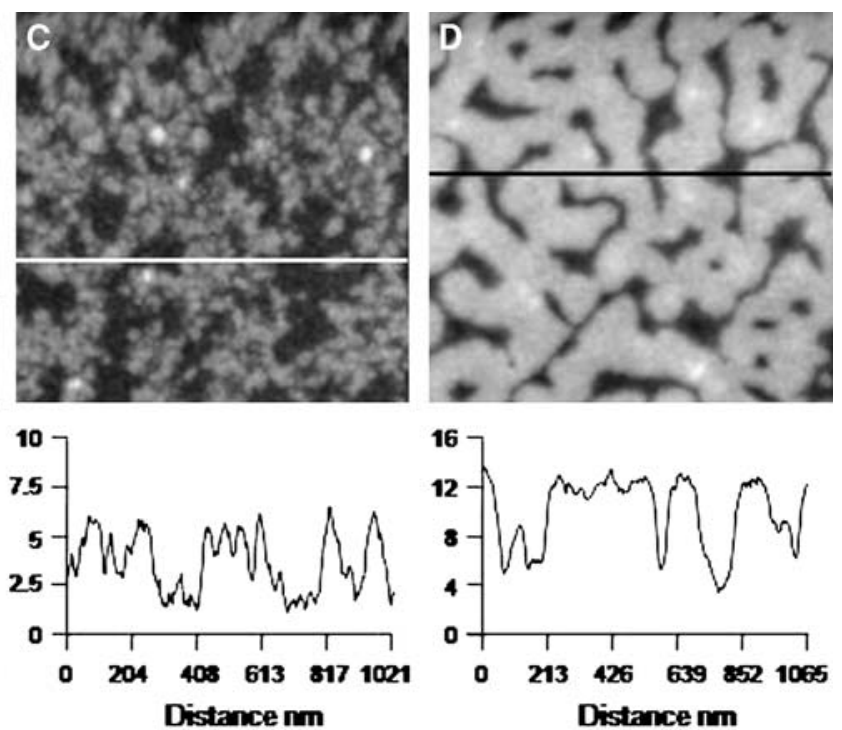
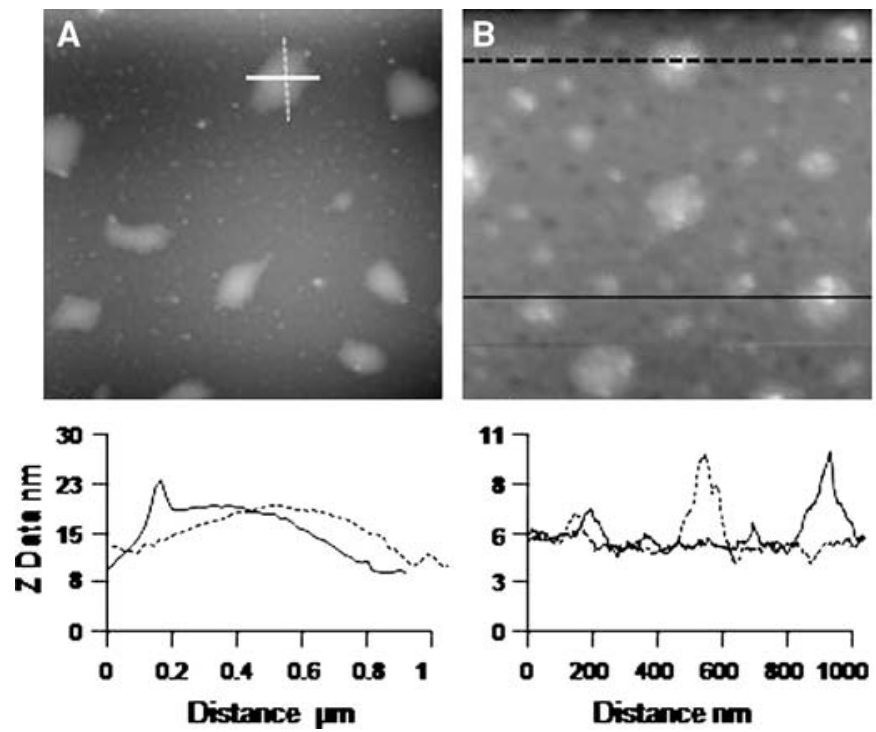

Fig. 3 AFM micrographs of a dehydrated lipopeptide extract. Ten microliters of a lipopeptide solution (approximately $5 \mathrm{mg} \mathrm{mL}^{-1}$ ) was added to mica $(\mathbf{a}-\mathbf{b})$ and to silicon $(\mathbf{c}-\mathbf{d})$ and allowed to dry. The dimensions of selected aggregates are indicated in the corresponding

iturins (compare Fig. 4e-f). Although fungal cells were damaged by the lipopeptide treatment, an increase of $15 \%$ of volume of fungal/lipopeptide aggregates was observed. This is explained because the reduction in hyphae structure is compensated by formation of aggregates of lipopeptides and cell debris (indicated by arrows in Fig. 4). Complete disintegration occurs when cells are treated with a $100 \mathrm{mM}$ solution of iturins as shown in the OM image of Fig. $4 \mathrm{~b}$, confirming a membrane solubilization effect.

Effect of lipopeptides on gram-negative bacterial cells

The plant pathogens Xcc and Xac were analyzed by AFM (Figs. 5, 6). Cells were treated with a high concentration of iturins $(5 \mathrm{mM})$. An estimation of iturin concentration was obtained from HPLC analysis. Preliminary tests on the cross-sections bellow the micrograph. On mica $(\mathbf{a}-\mathbf{b})$, vesicles or lamellar structures are shown in $\mathbf{a}$; micelles can be seen in $\mathbf{b}$. Silicon micrographs also indicate formation of aggregates of various sizes, with very large structures formed at the border of the drop (d)

effect of diluted solutions of lipopeptides on Xanthomonas cells indicated a MIC of $68 \mathrm{mg} \mathrm{mL}^{-1}$ for Xac (iturins

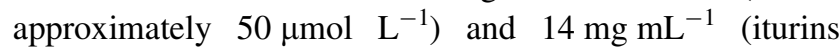
approximately $10 \mu \mathrm{mol} \mathrm{L}^{-1}$ ) for Xcc. A very high concentration of lipopeptides induced dramatic changes on the morphology of Xcc cells, including shrinkage and leakage of intracellular material in addition to destruction of cell wall, possibly given by a solubilization effect. Before treatment with the lipopeptide solution (Fig. 5a), cells presented a layer possibly formed by extracellular polymeric substances (EPS) commonly associated with the virulence of Xanthomonas (Kamoun and Kado 1990). Considering the effect on Xcc cells, parameters by AFM before and after treatment with lipopeptides had average dimensions of $2.4 \pm 0.3 \mu \mathrm{m} \quad$ (length), $\quad 1.6 \pm 0.2 \mu \mathrm{m} \quad$ (width) and $55 \pm 7 \mu \mathrm{m}$ (height). However, after treatment with antibi- 
Fig. 4 Effect of iturins on fungal cells. An optical microscopy (OM) micrograph with a magnification of 50 times is shown in a and $\mathbf{b}$. Images corresponding to non-treated cells are shown in a (OM), $\mathbf{c}$ and $\mathbf{g}$ (AFM). Lipopeptide treated samples are shown in b (OM/100 $\mathrm{mM}$ iturins), $\mathbf{e}$ and $\mathbf{h}$ (AFM/5 $\mathrm{mM}$ iturins). In $\mathbf{d}$ and $\mathbf{f}$ the vertical profiles of cross-sections (straight lines) are shown. The AFM micrographs allow a comparison of the area indicated by the arrows before ( 1 and 2) and after ( 3 and 4$)$ treatment with lipopeptides, demonstrating a reduction in fungal hyphae and formation of a novel structure. This is confirmed by the volumetric information before (g) and after (h) lipopeptide treatment, obtained using SPM Image Magic, which indicates an increment of $15 \%$ in volume
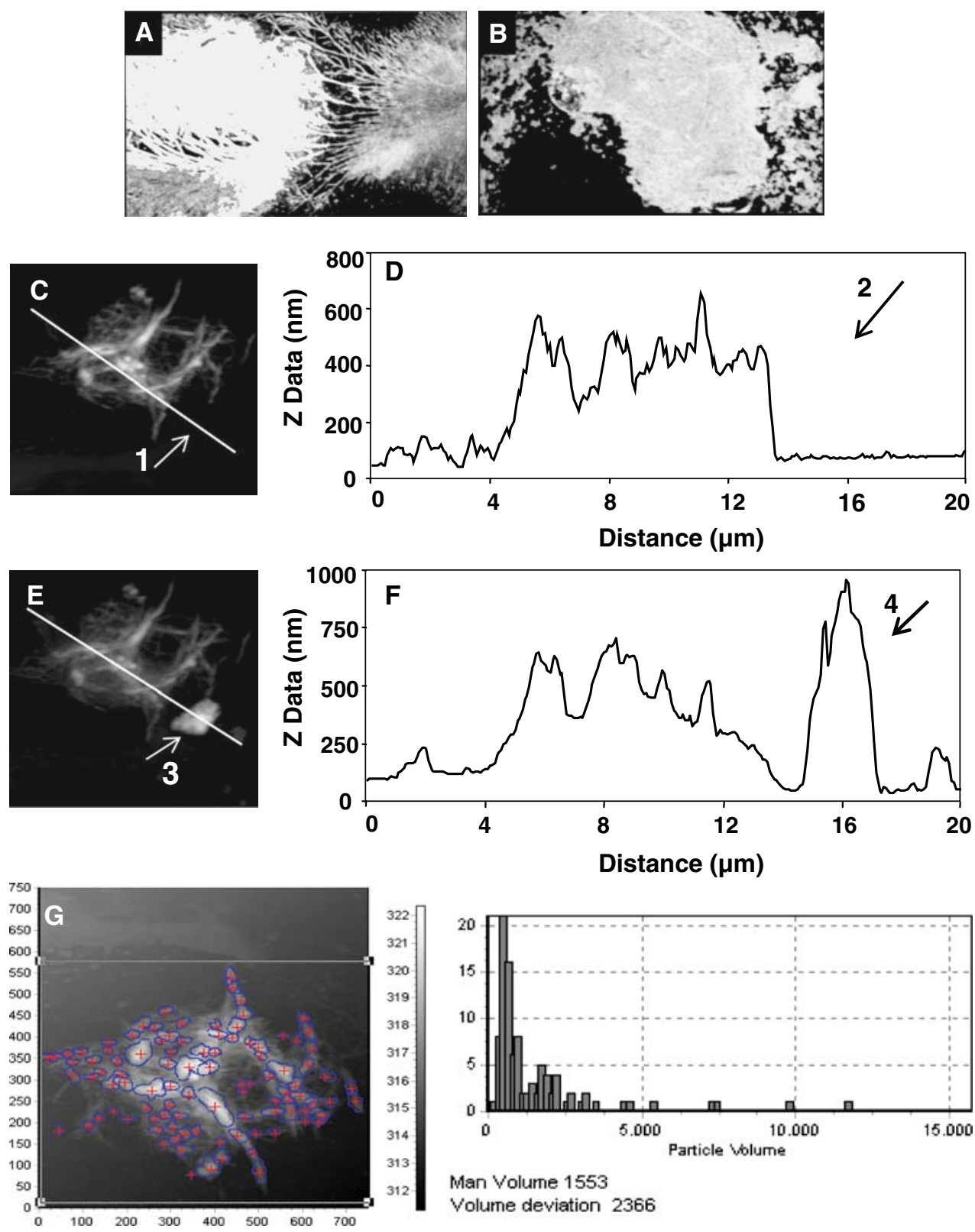

Man Volume 1553

Volume deviation 2366
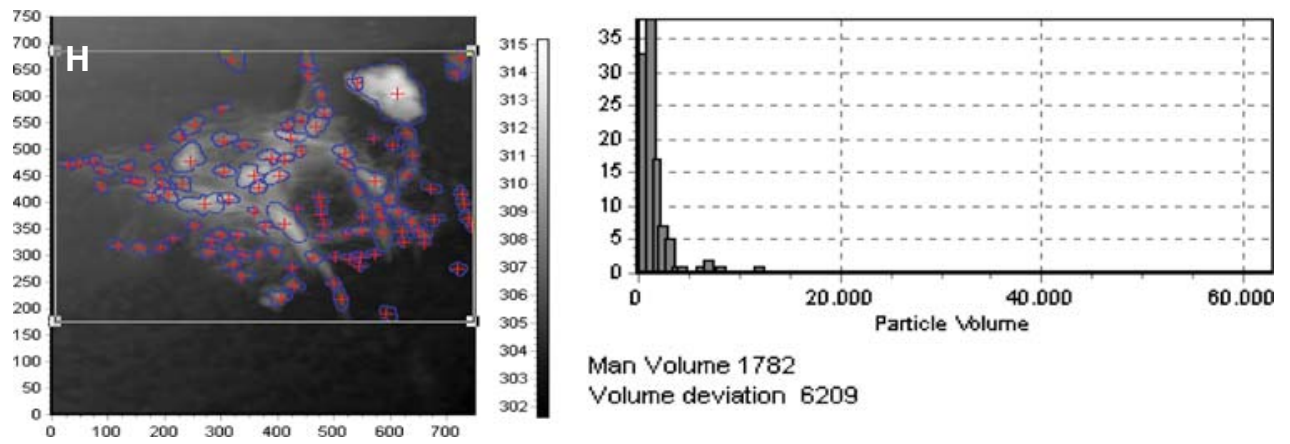

Man Volume 1782

Volume deviation 6209 otic a dramatic decrease in cell height was observed within the boundaries of the cell. It is possible that EPS, cell debris, intracellular material, and lipopeptide mixed with hydrophobic constituents of the cell wall have accumulated at the borders of the original cell structure (Fig. 5b-e). Fractal studies also confirm these observations. A fractal dimension greater than two is normally associated with volume (Christofoletti 1999; Ramakrishnan and Sadana 2002). Analysis 
Fig. 5 Effect of lipopeptides on Xcc cells observed by AFM. Images of Xcc were taken before treatment (a and $\mathbf{c}$ ) and after treatment with lipopeptides (b and e). As shown, Xcc cells were completely disintegrated. Cell debris have accumulated at the borders of the original cell structure (b and $\mathbf{e}$ ). Cross-sections of cells before and after lipopeptide treatment are shown in $\mathbf{d}$ and $\mathbf{f}$. As indicated in both cases the hatched line (1) is associated with cell length, whereas the solid line (2) allows one to measure and observe the vertical profile associated to the width of the cell. An arrow in e and $\mathbf{f}$ indicates a major groove within the damaged cell
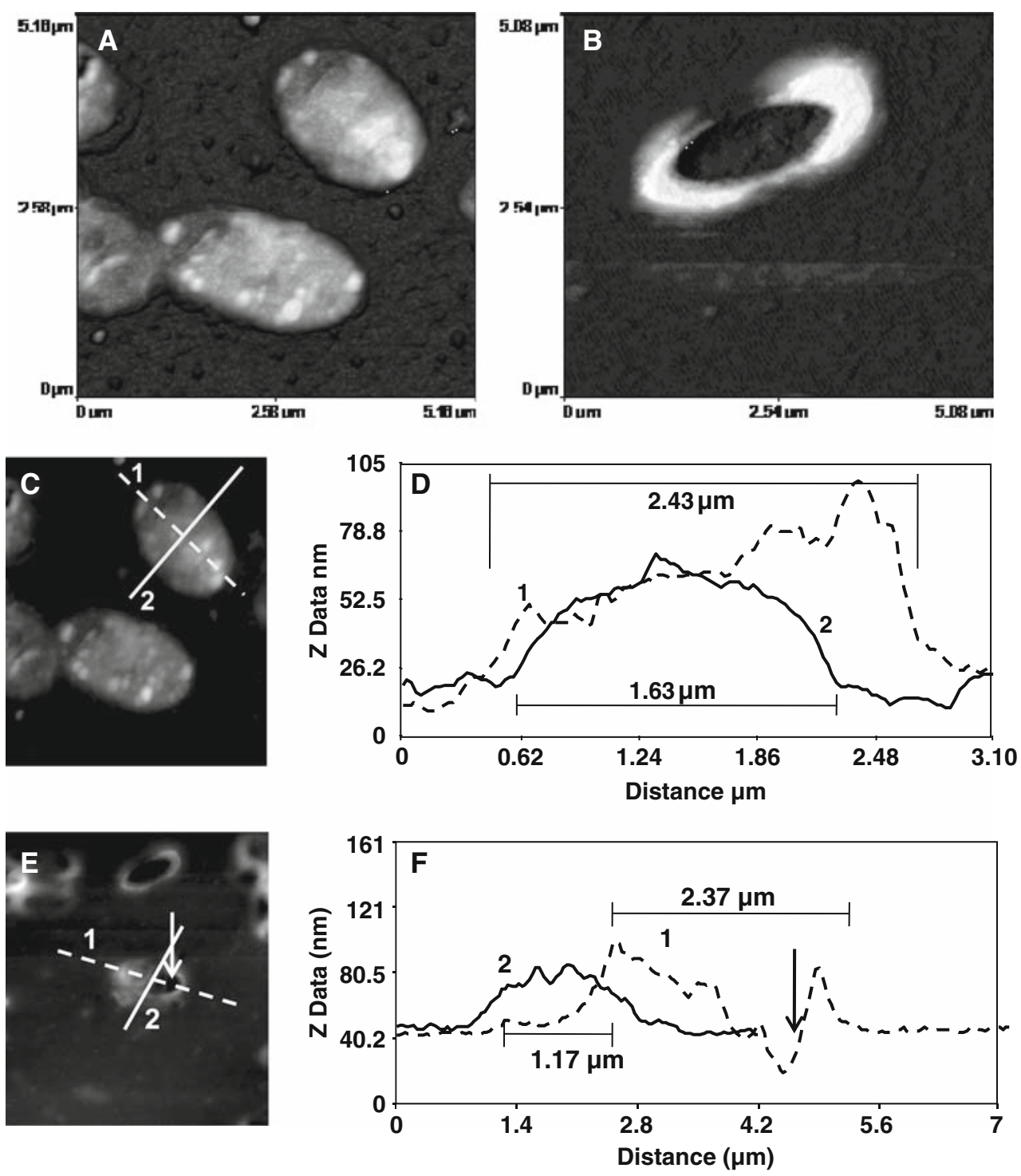

performed with the Gwyddion 2.5 software produced a fractal dimension of 2.30 for Xcc cells before the addition of lipopeptides. After treatment, a dimension of 1.68 was obtained, indicating that cells lost the volumetric information. The effect of lipopeptides on Xac (Fig. 6) was not as dramatic as described for Xcc. Cells became flatter and crumpled after treatment with lipopeptides (Fig. 6b, e, f). Comparing the width of a Xac cell before $(1.5 \mu \mathrm{m})$ and after lipopeptide treatment $(2.4 \mu \mathrm{m})$ a swelling effect is observed. Additionally, a different degree of roughness was observed upon treatment with lipopeptides, a cell surface that was initially soft became crumbled (compare Fig. 6a-b).

\section{Discussion}

A great variety of chemical structures, including amino acid sequences that constitute peptide antibiotics, generates positive, negative, and neutral antibiotics (Hancock and Chapple 1999). Contributing to structure diversity we find the non-ribosomally assembled peptides produced by bacteria and fungi (Etchegaray et al. 2004b).

Isoforms of the lipopeptides iturin and surfactin, two classes of non-ribosomal peptides produced by $B$. subtilis that et al. 2003), were found in the extract of B. subtilis strain OG. However, none of these are basic peptides, which are most active on bacterial membranes (Hancock and Chapple 1999). Iturins are neutral (Maget-Dana and Peypoux 1994) and surfactin is acidic, presenting a negative charge from mildly acid to high $\mathrm{pH}$ values (Maget-Dana and Ptak 1995). Two types of basic peptide antibiotics produced by B. Subtilis have been reported to date, the chlorotetaines (Phister et al. 2004) and the plipastatins (Umezawa et al. 1986; Tsuge et al. 1996). However, neither chlorotetaine (m/z 289-291) nor plipastatin peaks $(\mathrm{m} / \mathrm{z}$ in the range of have a cyclic peptide moiety linked to a fatty acid (Bonmatin 
Fig. 6 AFM micrographs showing the effect of lipopeptides on Xac cells. Pictures $\mathbf{a}$ and c show images before the addition of lipopeptides. Micrographs $\mathbf{b}$ and $\mathbf{e}$ correspond to lipopeptide treated cells. Damages that can be observed are a swelling and crumpling effect (b). Cross-sections before (d) and after (f) lipopeptide treatment also contribute to these conclusions (cell dimensions are indicated)
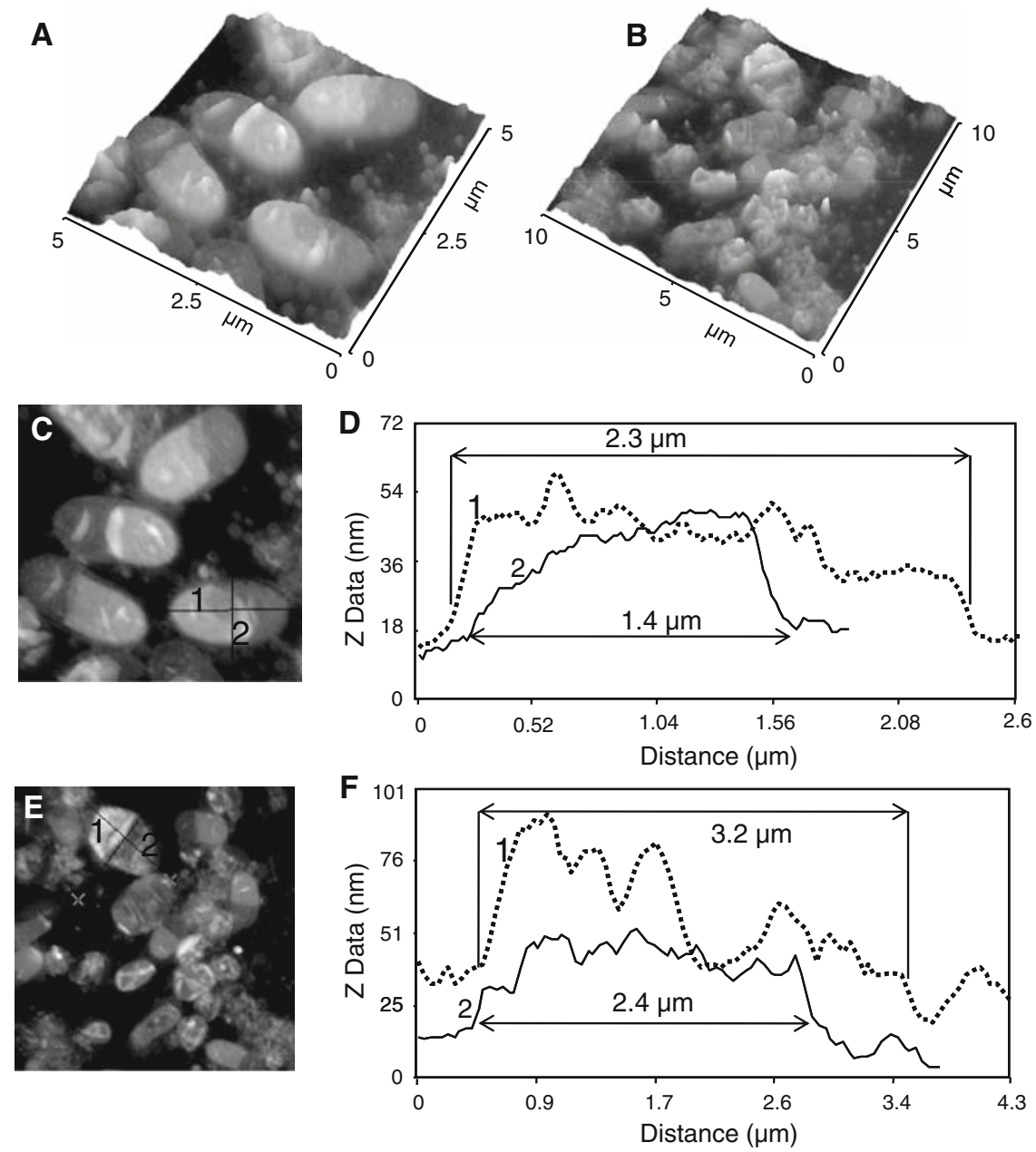

1,460-1,500) were detected in the extract of strain OG (Fig. 1). Considering that the extraction procedure would remove the more polar chlorotetaines, we cannot ignore the possible contribution of plipastatins if present in lower amounts, since these were not detected by mass-spectrometry.

Iturins and surfactins form aggregates (micelles) at low concentrations and possibly lamellar structures at higher concentrations (Grau et al. 2001), which may enhance their membrane interaction capacity as observed in the case of amphotericin (Legrand et al. 1992). In our experiments, before imaging by AFM, samples were desiccated. Under dry conditions, the local concentration of lipopeptides is significantly increased, therefore auto-organization and formation of aggregates is induced. In fact AFM analysis of a concentrated solution of lipopeptides added to muscovite mica and silicon showed horizontal and vertical aggregation states (Fig. 3). Therefore, self-aggregation may be an important contribution for the membrane interaction and cell-morphology modifications induced by the lipopeptide extract on bacterial cells as previously observed by Legrand et al. (1992) for amphotericin.

The mode of action of positively charged anti-microbial peptides, which is based on a self-promoted uptake across the cytoplasmic membrane, followed by interference with the cytoplasmic membrane barrier, is most commonly accepted (Hancock and Chapple 1999). The amphibian peptides magainins have been extensively studied. These ribosomaly made peptides are known to form amphipatic alpha-helices, which are important for their mode of action against gram-negative bacteria (Oren and Shai 1998; Hancock and Chapple 1999). It is a rational that the cationic and hydrophobic nature of the molecule is important for the initial binding and internalization of the peptide antibiotic at the lipopolysaccharide layer of gram-negative bacteria. However, according to this model uncharged molecules such as iturins, would not bind to bacterial membranes or contribute to the formation of pores. Nevertheless, our results demonstrate that aggregates of iturins mixed with surfactin (also identified in the lipopeptide extract) due interact with gram-negative bacteria. AFM analysis demonstrates dramatic changes on cell morphologies induced by these lipopeptides.

When an area of $100 \mu \mathrm{m}^{2}$ of the mica surface containing bacterial cells was scanned and compared before and after incubation with lipopeptides, it was deduced that $100 \%$ of Xcc cells presented morphological modification including 
dramatic volume reduction confirmed by fractal analysis. However, a similar analysis of the effect of lipopeptides on Xac cells indicated that approximately $36 \%$ of the cells within the $100 \mu \mathrm{m}^{2}$ area presented morphological modifications visualized by AFM. Fractal analysis of Xac cells did not show significant variations upon treatment (data not shown), one reason is that cells may have lost height but at the same time they became flat and swollen, thus keeping the same volume. In addition, lipopeptides attached to the cell surface may have contributed for the volume calculated by fractal analysis.

Whereas the antifungal activity of iturins and surfactins is well studied, the antibacterial action of iturins remains unsettled. The antibacterial activity of surfactins has been demonstrated at high concentrations (Vollenbroich et al. 1997; Huang et al. 2007). Another important application described for this lipopeptide is the binding at lipopolysaccharides in gram-negative bacteria with consequent reduction of septic shock (Hwang et al. 2007). Here, we have demonstrated that a mixture of iturins and surfactin at high concentration can bind and dramatically modify the surface of Xcc, a gram negative phytopathogen. A possible explanation for these results is that the mode of action of iturins may involve formation of mixed aggregates with other lipopeptides present in the extract including surfactin. These organized structures may remove positively charged cations such as calcium and/or magnesium that may be found attached to the negatively charged cell wall. Removal of cations can induce a collapse of the cell wall, contributing for lipopeptide integration into the membrane, and thus formation of pores. The chelating agent EDTA enhances the permeability of bacterial cells by a similar mechanism (Zhang et al. 2000; da Silva and Teschke 2003). In a study on the haemolytic activity of iturins it was found that these lipopeptides are able to induce leakage of intracellular compounds in human erythrocyte ghosts but not in large unilamellar liposomes, which are made of various kinds of lipids (Aranda et al. 2005). In analogy, the surface of Xac cells may not be as permeable as the surface of Xcc cells, possibly due to the presence of additional extracellular hydrophobic material. In a previous work we have identified a gene cluster in the genome of Xac, which might be involved in lipopeptide biosynthesis (Etchegaray et al. 2004b).

In conclusion, considering that the lipopeptides present in the extract of strain OG have no positive charge, the present paper shows that an extract of iturin and surfactin was able to disintegrate the cell wall of the gram-negative phytopathogen Xcc. One possibility is that the affinity of iturins and surfactins for calcium may have promoted the uptake of these peptides into the negatively charged bacterial membrane by formation of positively-charged lipopeptide-calcium chelates. It has been shown by others that the addition of calcium ions induce structural changes and penetration of surfactins on artificial phospholipid membranes (Knoblich et al. 1995). A potential source of calcium is the bacterial outer membrane (Nikaido 2003).

Acknowledgments This research has been funded by the Fundação de Pesquisa de São Paulo (Fapesp grants 96/11193-7 and 03/12529-4) and the Conselho Nacional de Pesquisa (CNPq). We would like to thank the valuable research assistance of L. O. Bonugli and J. R. Castro. M. E. Silva-Stenico was the recipient of postdoctoral fellowship from FAPESP (Grant 2004/16042-5)

\section{References}

Allende D, Simon SA, McIntosh TJ (2005) Melittin-induced bilayer leakage depends on lipid material properties: evidence for toroidal pores. Biophys J 88:1828-1837. doi:10.1529/biophysj.104. 049817

Altschul SF, Gish W, Miller W, Myers EW, Lipman DJ (1990) Basic local alignment search tool. J Mol Biol 215:403-410

Aranda FJ, Teruel JA, Ortiz A (2005) Further aspects on the hemolytic activity of the antibiotic lipopeptide iturin A. Biochim Biophys Acta 1713:51-6. doi:10.1016/j.bbamem.2005.05.003

Birnboim HC, Doly J (1979) A rapid alkaline extraction procedure for screening recombinant plasmid DNA. Nucleic Acids Res 7:15131523

Bonmatin J-M, Laprévote O, Peypoux F (2003) Diversity among microbial cyclic lipopeptides: iturins and surfactins. Activitystructure relationships to design new bioactive agents. Comb Chem High Throughput Screen 6:541-556

Besson F, Peypoux F, Michel G, Delcambe L (1976) Characterization of iturin A in antibiotics from various strains of Bacillus subtilis. J Antibiot 29:1043-1049

Christofoletti A (1999) Modelagem de Sistemas Ambientais. Edgard Blucher, São Paulo

Cook RJ, Thomashow LS, Weller DM, Fujimoto D, Mazzola M, Bangera G, Kim DS (1995) Molecular mechanisms of defense by rhizobacteria against root disease. Proc Natl Acad Sci USA 92:4197-4201

da Silva A Jr, Teschke O (2003) Effects of the antimicrobial peptide PGLa on live Escherichia coli. Bioch Biophys Acta 1643:95-103. doi:10.1016/j.bbamcr.2003.10.001

Dufrêne YF (2002) Atomic force microscopy, a powerful tool in microbiology. J Bacteriol 184:5205-5213. doi:10.1128/JB.184. 19.5205-5213.2002

Etchegaray A, Rabello E, Dieckmann R, Moon DH, Fiore MF, von Döhren H, Tsai SM, Neilan BA (2004a) Algicide production by the filamentous cyanobacterium Fischerella sp. CENA 19. J Appl Phycol 16:237-243. doi:10.1023/B:JAPH.0000048509.77816.5e

Etchegaray A, Silva-Stenico ME, Moon DH, Tsai SM (2004b) In silico analysis of nonribosomal peptide synthetases of Xanthomonas axonopodis pv. citri: identification of putative siderophore and lipopeptide biosynthetic genes. Microbiol Res 159:425-437. doi:10.1016/j.micres.2004.09.009

Gong M, Wang JD, Zhang J, Yang H, Lu XF, Pei Y, Cheng JQ (2006) Study of the antifungal ability of Bacillus subtilis strain PY-1 in vitro and identification of its antifungal substance (iturin A). Acta Biochim Biophys Sin 38:233-240. doi:10.1111/j.1745-7270. 2006.00157.x

Grau A, Gómez-Fernández JC, Peypoux F, Ortiz A (2001) Aggregational behavior of aqueous dispersions of the antifungal lipopeptide iturin A. Peptides 22:1-5. doi:10.1016/S0196-9781(00) 00350-8 
Hancock RE, Chapple DS (1999) Peptide antibiotics. Antimicrob Agents Chemoter 43:1317-1323

Huang X, Wei Z, Zhao G, Gao X, Yang S, Cui Y (2007) Optimization of sterilization of Escherichia coli in milk by surfactin and fengycin using a response surface method. Curr Microbiol 56:376-381. doi: 10.1007/s00284-007-9066-8

Hwang YH, Park BK, Lim JH, Kim MS, Park SC, Hwang MH, Yun HI (2007) Lipopolysaccharide-binding and neutralizing activities of surfactin C in experimental models of septic shock. Eur J Pharmacol 556:166-171. doi:10.1016/j.ejphar.2006.10.031

Ivanova EP, Vysotskii MV, Svetashev VI, Nedashkovskaya OI, Gorshkova NM, Mikhailov VV, Yumoto N, Shigeri Y, Taguchi T, Yoshikawa S (1999) Characterization of Bacillus strains of marine origin. Int Microbiol 2:267-271

Kim JG, Park BK, Yoo CH, Jeon E, Oh J, Hwang I (2003) Characterization of the Xanthomonas axonopodis pv. glycines Hrp pathogenicity island. J Bacteriol 185:3155-3166. doi:10.1128/ JB.185.10.3155-3166.2003

Knoblich A, Matsumoto M, Ishiguro R, Murata K, Fujiyoshi Y, Ishigami Y, Osman M (1995) Electron cryo-microscopic studies on micellar shape and size of surfactin, an anionic lipopeptide. Coll Surf Biointerf 5:43-48. doi:10.1016/0927-7765(95)01207-Y

Kumar S, Tamura K, Nei M (2004) MEGA3: integrated software for molecular evolutionary genetics analysis and sequence alignment. Brief Bioinform 5:150-163

Lane DJ (1991) 16S/23S rRNA sequencing. In: Stackebrandt E, Goodfellow M (eds) Nucleic acid techniques in bacterial systematic. Chichester, Wiley, pp 115-175

Legrand P, Romero EA, Cohen BE, Bolard J (1992) Effects of aggregation and solvent on the toxicity of amphotericin B to human erythrocytes. Antimicrob Agents Chemother 36:2518-2522

Leclère V, Béchet M, Adam A, Guez JS, Wathelet B, Ongena M, Thonart P, Gancel F, Chollet-Imbert M, Jacques P (2005) Mycosubtilin overproduction by Bacillus subtilis BBG100 enhances the organism's antagonistic and biocontrol activities. Appl Environ Microbiol 71:4577-4584

Maget-Dana R, Peypoux F (1994) Iturins, a special class of poreforming lipopeptides: biological and physicochemical properties. Toxicol 8:151-74

Maget-Dana R, Ptak M (1995) Interactions of surfactin with membrane models. Biophys J 68:1937-1943

Maget-Dana R, Thimon L, Peypoux F, Ptak M (1992) Surfactin/iturin A interactions may explain the synergistic effect of surfactin on the biological properties of iturin A. Biochimie 74:1047-1051

Monteiro L, Mariano RLR, Souto-Maior AM (2005) Antagonism of Bacillus spp. against Xanthomonas campestris. Braz Arch Biol Technol 48:23-29

Meincken M, Holroyd DL, Rautenbach M (2005) Atomic force microscopy study of the effect of antimicrobial peptides on the cell envelope of Escherichia coli. Antimicrob agents chemother 49:4085-4092. doi:10.1128/AAC.49.10.4085-4092.2005

Neilan BA, Jacobs D, Del Dot T, Blackall LL, Hawkins PR, Cox PT, Goodman AE (1997) rRNA sequences and evolutionary relationships among toxic and nontoxic cyanobacteria of the genus $\mathrm{Mi}$ crocystis. Int J Syst Bacteriol 47:693-697
Nikaido H (2003) Molecular Basis of bacterial outer membrane permeability revisited. Microbiol Mol Biol Rev 67:593-656. doi:10.1128/MMBR.67.4.593-656.2003

Oren Z, Shai Y (1998) Mode of action of linear amphipathic alphahelical peptides. Biopolymers 47:451-463

Phister TG, O'Sullivan DJ, McKay LL (2004) Identification of bacilysin, chlorotetaine, and iturin A produced by Bacillus sp. strain CS93 isolated from pozol, a Mexican fermented maize dough. Appl Environ Microbiol 70:631-634. doi:10.1128/AEM.70.1. 631-634.2004

Ramakrishnan A, Sadana A (2002) A mathematical analysis using fractals for binding interactions of nuclear estrogen receptors occurring on biosensor surfaces. Anal Biochem 303:78-92. doi:10.1006/abio.2002.5581

Razafindralambo H, Popineau Y, Deleu M, Hbid C, Jacques P, Tonart P, Paquot M (1997) Surface-active properties of surfactin/iturin A mixtures produced by Bacillus subtilis. Langmuir 13:6026-6031

Razafindralambo H, Paquot M, Hbid C, Jacques P, Destain J, Thonart $\mathrm{P}$ (1993) Purification of antifungal lipopeptides by reversed-phase high-performance liquid chromatography. J Chromatogr 639:8185

Romero D, de Vicente A, Olmos JL, Dávila JC, Pérez-García A (2007) Effect of lipopeptides of antagonistic strains of Bacillus subtilis on the morphology and ultrastructure of the cucurbit fungal pathogen Podosphaera fusca. Appl Microbiol 103:969-976. doi:10.1111/j.1365-2672.2007.03433.x

Sprencel C, Cao Z, Qi Z, Scott D, Montague M, Ivanoff N, Xu J, Raymond K, Newton S, Klebba P (2000) Binding of ferric enterobactin by the Escherichia coli periplasmic protein FepB. J Bacteriol 182:5359-5364

Thimon L, Peypoux F, Wallach J, Michel G (1995) Effect of the lipopeptide antibiotic, iturin $\mathrm{A}$, on morphology and membrane ultrastructure of yeast cells. FEMS Microbiol Lett 128:101-106

Thompson JD, Gibson TJ, Plewniak F, Jeanmougin F, Higgins DG (1997) The CLUSTAL_X windows interface: flexible strategies for multiple sequence alignment aided by quality analysis tools. Nucleic Acids Res 25:4876-4882

Tsuge K, Akiyama T, Shoda M (2001) Cloning, Sequencing, and Characterization of the Iturin A Operon. J Bacteriol 183:6265-6273

Tsuge K, Ano T, Shoda M (1996) Isolation of a gene essential for biosynthesis of the lipopeptide antibiotics plipastatin B1 and surfactin in Bacillus subtilis YB8. Arch Microbiol 165:243-251

Umezawa H, Aoyagi T, Nishikiori T, Okuyama A, Yamagishi Y, Hamada M, Takeuchi T (1986) Plipastatins: new inhibitors of phospholipase A2, produced by Bacillus cereus BMG302-fF67. I. Taxonomy, production, isolation and preliminary characterization. J Antibiot 39:737-44

Vollenbroich D, Pauli G, Muhsin OZ, Vater J (1997) Antimycoplasma properties and application in cell culture of surfactin, a lipopeptide antibiotic from Bacillus subtilis. Appl Environ Microbiol 63:44-49

Zhang L, Dhillon P, Yan H, Farmer S, Hancock REW (2000) Interactions of bacterial cationic peptide antibiotics with outer and cytoplasmic membranes of Pseudomonas aeruginosa. Antimicrob agents chemother 44:3317-3321 